\title{
Effect of internal bleaching agents on the bond strength of glass fiber posts to root dentine
}

Josemar Martins Ferreira ${ }^{a}$, Sara Rodrigues Renovato ${ }^{a}$, Fernanda Ribeiro Santana ${ }^{b}$, Daniel de Almeida Decurcio ${ }^{b}$, Carlos José Soares ${ }^{a}$, Carlos Estrela ${ }^{b}$

\begin{abstract}
Objective: This study evaluated the effect of internal bleaching agents on the bond strength of glass fiber posts to root dentine.

Methods: Seventy bovine teeth were divided into 7 experimental groups $(n=10)$ according to the bleaching agent used: $\mathrm{SpH}$ - sodium perborate $+20 \%$ hydrogen peroxide; $\mathrm{SpW}$ - sodium perborate + distilled water; Cp37 - 37\% carbamide peroxide; Cp16 - 16\% carbamide peroxide; Cp10 - 10\% carbamide peroxide; $\mathrm{H}-35 \%$ hydrogen peroxide; $\mathrm{C}$ - no bleaching agent (control). After bleaching, posts were cemented with a self-adhesive resin cement (RelyX U100) and the roots were crosssectioned to obtain two discs from each third. The posts underwent micropush-out testing, and bond strength values (MPa) were analyzed using ANOVA in a split-plot arrangement and the Tukey test $(p<0.05)$. Failure mode was evaluated under confocal microscopy.

Results: There were no significant differences between the control and bleaching agent groups. Bond strength was greater in the cervical third of the 16\% carbamide peroxide (Cp16) group than in the sodium perborate $+20 \%$ hydrogen peroxide $(\mathrm{SpH})$ group. The cervical third had a higher bond strength than the apical third in the 10\% carbamide peroxide (Cp10), 16\% carbamide peroxide (Cp16) and sodium perborate + distilled water (SpW) groups, and no significant differences in the other groups. Adhesive cement-dentine failure was prevalent in all groups.

Conclusion: The use of internal bleaching agents did not decrease the bond strength of glass fiber posts to root dentin.
\end{abstract}

Key words: Internal bleaching; Glass fiber posts; Bonding

\section{Efeito de agentes clareadores internos na resistência de união de pinos de fibra de vidro com a dentina radicular}

\section{RESUMO}

Objetivo: Este estudo avaliou o efeito de agentes clareadores internos na resistência de união entre pinos de fibra de vidro e a dentina radicular.

Métodos: Setenta dentes bovinos foram divididos em 7 grupos experimentais $(n=10)$ de acordo com o agente de clareamento usado: $\mathrm{SpH}$ - perborato $+20 \%$ de peróxido de hidrogénio e sódio; SPW - perborato de sódio + água destilada; Cp37 - 37\% de peróxido de carbamida; CP16 - 16\% de peróxido de carbamida; CP10 - 10\% de peróxido de carbamida; $\mathrm{H}-35 \%$ de peróxido de hidrogénio; $\mathrm{C}$ - nenhum agente clareador (controle). Após oclareamento, pinos foram cimentados com cimento resinoso auto-adesivo (RelyX U100) e as raízes foram seccionadas transversalmente para se obter dois discos de cada terço. As pinos foram submetidos a testes micropush-out, e os valores de resistência de união (MPa) foram analisados por ANOVAde duas vias, e o teste de Tukey $(p<0,05)$. Falhas foram avaliada em microscopia confocal.

Resultados: Não houve diferenças significativas entre os grupos de agentes de controle e de clareamento. A resistência de união foi maior no terço cervical do grupo de peróxido de carbamida 16\% (CP16) do que no grupo perborato de sódio + peróxido de hidrogênio 20\% (SPH). O terço cervical tinha uma força de ligação superior ao terço apical do peróxido de carbamida a 10\% (CP10), 16\% de peróxido de carbamida (CP16) e perborato de sódio + grupos água destilada (SPW), e não houve diferenças significativas nos outros grupos. Falhas adesivas de cimento-dentina foi prevalente em todos os grupos.

Conclusão: $\mathrm{O}$ uso de agentes clareadores internos não diminuiu a resistência de união de pinos de fibra de vidro à dentina radicular.

Palavras-chave: Clareamento interno; Pinos de fibra de vidro; Adesão

\author{
${ }^{a}$ Federal University of Uberlândia (UFU), Uber- \\ lândia, MG, Brazil \\ ${ }^{\mathrm{b}}$ Federal University of Goiás (UFG), Goiânia, GO \\ Brazil
}

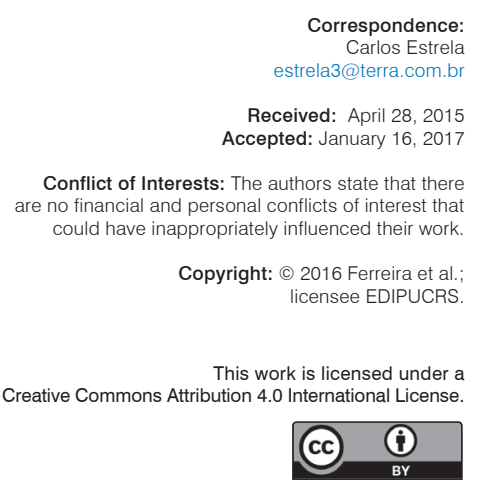

http://creativecommons.org/licenses/by/4.0 


\section{INTRODUCTION}

An attractive smile may be compromised by tooth color, and discoloration of a tooth is an aesthetic change that usually requires treatment [1]. Common causes of discoloration of pulpless teeth are injury or breakdown of pulp tissue, intrinsic changes due to intrapulpal hemorrhage and chromophores within the root canal $[2,3]$.

Since the nineteenth century, several substances, such as potassium cyanide [4], oxalic acid [5], aluminum chloride [6], and permanganate potassium combined with various other substances [7], have been used for bleaching of pulpless teeth. Most have been discarded due to undesirable side effects, such as tooth staining by the products used in the reaction and the possible weakening of tooth structure, and only hydrogen peroxide $\left(\mathrm{H}_{2} \mathrm{O}_{2}\right)$ and sodium perborate $\left(\mathrm{NaBO}_{3}\right)$ remain in use [8].

Several studies evaluated the deleterious effects of bleaching agents on dentine bond to composite, and many reported that if the adhesive procedure is performed after bleaching, there is a reduction of bond strength that may be significant [9-14]. However, few studies in the literature evaluated bonding to root dentine after internal bleaching of endodontically treated teeth. These teeth usually have insufficient coronal structure to retain restorative material, and a post has to be used for coronal reconstruction. Glass fiber posts and resin cement are widely accepted today as alternatives to cast posts [15-19].

This study evaluated the effect of internal bleaching agents on bond strength of adhesively cemented (RelyX U100; 3M-ESPE, St. Paul, MN, USA) glass fiber posts to root dentine and tested whether the use of internal bleaching agents reduced the bond strength of glass fiber posts to root dentine

\section{METHODS}

Extracted bovine incisors were stored in distilled water under refrigeration after all periodontal tissues had been removed. Of 300 freshly extracted teeth, 70 were selected because of their similarity in external and internal anatomy. They were divided into seven groups $(n=10)$, according to bleaching agent: $\mathrm{SpH}-$ sodium perborate $+20 \%$ hydrogen peroxide (Whiteness Perborato, FGM, Joinville, Brazil); $\mathrm{SpW}$ - sodium perborate + distilled water (Whiteness Perborato, FGM, Joinville, Brazil); Cp37 - 37\% carbamide peroxide (Whiteness Super-Endo, FGM, Joinville, Brazil); Cp16 - 16\% carbamide peroxide (Whiteness Perfect 16\%, FGM, Joinville, Brazil); Cp10 - 10\% carbamide peroxide (Whiteness Perfect 10\%, FGM, Joinville Brazil); H - 35\% hydrogen peroxide (Whiteness HPMaxx, FGM, Joinville, Brazil); C (control) - no bleaching agent.

The crowns were cross-sectioned using a double-faced diamond disc under water cooling to get a remaining crown of $10 \mathrm{~mm}$ from the cementoenamel junction. Root canals were prepared $1 \mathrm{~mm}$ short of the apex using a crown-down technique and rotary Ni-Ti instruments of the K3 System
(SybronEndo, Orange, CA) in the following sequence: \#25 .10 taper; \#15-25 .02 taper; \#25 .04 taper; \#25 .06 taper and \#30-45 .02 taper. Continuous irrigation with 1\% sodium hypochlorite was used during root canal preparation.

The root canals were filled with gutta-percha and a calcium hydroxide-based sealer (Sealapex, SybronEndo, Orange, CA) using the lateral condensation technique. Excess gutta-percha was removed, and vertical condensation was performed. After that, $4 \mathrm{~mm}$ of root canal filling was removed with a heated instrument, and a conventional glass ionomer (Maxxion R, FGM, Joinville, Brazil) was used for a 2-mm coronal sealing according to the instructions of the bleaching agent manufacturer. The glass ionomer seal was $2 \mathrm{~mm}$ below the cervical margin.

In the $\mathrm{C}$ group (control), no bleaching agent was used; the pulp chamber was filled with a cotton pellet and sealed with conventional glass ionomer. In the $\mathrm{SpW}$ and $\mathrm{SpH}$ groups, the bleaching agents were prepared according to the manufacturer's instructions at a 2:1 ratio (powder/liquid) and inserted into the pulp chamber. After that, a small flat cotton pellet was inserted into the pulp chamber, which was then sealed with conventional glass ionomer (Maxxion R, FGM, Joinville, Brazil) (walking bleach technique). A total of 4 applications were performed at an interval of 3 days between each change. During this time, the teeth were kept in distilled water at about $37^{\circ} \mathrm{C}$. In groups $\mathrm{Cp} 10, \mathrm{Cp} 16$ and $\mathrm{Cp} 37$, the agents did not require preparation and were applied in the same way as in the $\mathrm{SpW}$ and $\mathrm{SpH}$ groups. At last, in the $\mathrm{H}$ group, the material was prepared at a ratio of 3 drops of phase 1 (peroxide) to 1 drop of phase 2 (thickener), applied to the buccal surface and into the pulp chamber, and light-cured for $40 \mathrm{~s}$ (Radii-Cal, SDI, Bayswater, Australia) on the buccal and lingual surfaces [21]. After 3 applications, the teeth were washed and sealed with a cotton pellet and conventional glass ionomer (Maxxion R, FGM, Joinville, Brazil). In all groups, post preparation started only 7 days after bleaching, according to the manufacturer's instructions.

For post preparation, the crown was removed and the post space was prepared using \#3-5 Largo burs (Dentsply Maillefer, Ballaigues, Switzerland) (WL10mm), which correspond to a parallel-sided and serrated glass fiber post of 1.5-mm diameter (Reforpost \#3; Angelus, Londrina, Brazil). The root canals were irrigated at each change of burs and after the preparation with $2 \mathrm{~mL}$ of $1 \%$ sodium hypochlorite and dried with absorbent paper points. All roots were covered externally with wax to avoid lateral polymerization [21].

Glass fiber posts were cleaned with $70 \%$ alcohol in a single application using a microbrush, and a silane agent (Silano, Angelus, Londrina, Brazil) was applied after drying. The self-adhesive resin cement (RelyX U100; 3M-ESPE, St. Paul, MN) was prepared according to the manufacturer's instructions, introduced into the root canal with a K-File and placed on the post. The post was seated to full depth by finger pressure. Excess cement was removed after $1 \mathrm{~min}$. After $5 \mathrm{~min}$, the resin cement was light-cured using $1200 \mathrm{~mW} / \mathrm{cm}^{2}$ (Radii-Cal; SDI, Bayswater, Australia) for three 40-s applications, at a total of $120 \mathrm{~s}$ : (1) on the cervical 
face of the root; (2) along the long axis of the root; and (3) obliquely to the buccal and lingual surfaces. Samples were stored in distilled water at $37^{\circ} \mathrm{C}$ for $24 \mathrm{~h}$. After $24 \mathrm{~h}$, each root was serially sectioned perpendicular to its long axis with a double face diamond disc (4" dia. x 0.012" thickness x 1/2" Arbor, Extec, Enfield, CT) at low speed under water cooling (Isomet 1000, Buehler, Lake Bluff, IL) to obtain two discs about $1 \mathrm{~mm}$ thick from each third: cervical, middle and apical.

In all groups, the discs immediately underwent push-out tests in a universal testing machine (EMIC DL 2000, São José dos Pinhais, Brazil) by applying a compressive load at a speed of $0.5 \mathrm{~mm} / \mathrm{min}$ in the apical-coronal direction until post segment extrusion. Bond strength was calculated in MPa by dividing the load at failure (in N) by the area of the bonded interface. The area of the bonded interface was calculated as follows: $A=2 \pi \mathrm{rh}$, where $\mathrm{A}$ is the area of the bonded interface, $\pi$ is $3.14, \mathrm{r}$ is the radius of the post segment $(\mathrm{mm})$, and $\mathrm{h}$ is the thickness of the post segment (mm) [21-23].

The SAS 9.2 (Institute Inc., Cary, NC) was used for statistical analysis. The Shapiro-Wilk test was used to analyze data normality. One-way analysis of variance (ANOVA) in a split-plot arrangement was used to evaluate the effects of the bleaching agents on bond strength, where the whole plot was the bleaching agent, and the subplots, the root canal thirds. The Tukey test was used for multiple comparisons $(\alpha=.05)$.
To determine failure mode, all specimens were air dried and analyzed under a confocal laser scanning microscope (Carl Zeiss Laser Scanning Systems, LSM510, META, Oberkochen, Germany). Images were analyzed using the Zeiss LSM Image Browser (META, Germany). The failure mode was classified into six types: (i) adhesive between the post and resin cement; (ii) adhesive between resin cement and root dentine; (iii) cohesive in cement; (iv) cohesive in dentine; (v) cohesive in post; and (vi) mixed, between post, resin cement and root dentine [24,25].

\section{RESULTS}

One-way ANOVA (internal bleaching agent) with subplots (root canal thirds) showed significant differences for bleaching agent $(\mathrm{p}=.010)$ and root canal third $(\mathrm{p}<.001)$. The mean push-out bond strengths and standard deviations are shown in Table 1. The Tukey test revealed that Cp16 produced higher bond strength values than $\mathrm{SpH}$ in the cervical third. There were no significant differences between the control and bleaching agent groups. The cervical third had higher bond strength values than the apical third in the Cp10, Cp16 and SpW groups, and no significant differences in the other groups.

Failure distribution is shown in Table 2 and Figure 1. Adhesive cement-dentine failure was prevalent in all groups.

Table 1. Mean bond strength values in MPa (standard deviation) and statistical categories according to the Tukey test $(n=10)$.

\begin{tabular}{lccccccc}
\hline \multirow{2}{*}{ Root third } & \multicolumn{5}{c}{ Bleaching agent } \\
\cline { 2 - 7 } Cervical & No agent $(C)$ & H & Cp10 & Cp16 & Cp37 & SpW & SpH \\
Middle & $14.69 \pm 4.79^{\mathrm{ABa}}$ & $15.13 \pm 4.24^{\mathrm{ABa}}$ & $14.68 \pm 3.78^{\mathrm{ABa}}$ & $19.52 \pm 4.21^{\mathrm{Aa}}$ & $17.83 \pm 6.28^{\mathrm{ABa}}$ & $16.01 \pm 5.28^{\mathrm{ABa}}$ & $12.29 \pm 5.36^{\mathrm{Ba}}$ \\
Apical & $13.53 \pm 3.90^{\mathrm{ABa}}$ & $12.67+6.18^{\mathrm{ABa}}$ & $12.26 \pm 3.68^{\mathrm{ABab}}$ & $14.00 \pm 5.88^{\mathrm{ABb}}$ & $15.09 \pm 5.78^{\mathrm{Aa}}$ & $11.52 \pm 5.26^{\mathrm{ABab}}$ & $8.22 \pm 3.83^{\mathrm{Ba}}$ \\
\hline & $12.11 \pm 4.56^{\mathrm{ABa}}$ & $11.00+5.99^{\mathrm{ABa}}$ & $10.09 \pm 3.77^{\mathrm{ABb}}$ & $11.93 \pm 6.55^{\mathrm{ABb}}$ & $14.52 \pm 7.24^{\mathrm{Aa}}$ & $8.30 \pm 3.94^{\mathrm{ABb}}$ & $7.71 \pm 2.99^{\mathrm{Ba}}$ \\
\hline
\end{tabular}

$\mathrm{H}-35 \%$ hydrogen peroxide; Cp10 - 10\% carbamide peroxide; Cp16 - 16\% carbamide peroxide; Cp37 - 37\% carbamide peroxide; SpW - sodium perborate + distilled water; $\mathrm{SpH}$ - sodium perborate $+20 \%$ hydrogen peroxide.

Capital letters compare groups in horizontal lines and lower-case letters, in vertical lines.

Tukey test categories with same letter are not statistically different from each other $(p<0.05)$

Table 2. Failure modes for experimental groups.

\begin{tabular}{|c|c|c|c|c|c|c|}
\hline Groups (\%) & $\begin{array}{c}\text { Adhesive: } \\
\text { post and cement (i) }\end{array}$ & $\begin{array}{c}\text { Adhesive: } \\
\text { cement and dentine (ii) }\end{array}$ & $\begin{array}{l}\text { Cohesive: } \\
\text { Cement (iii) }\end{array}$ & $\begin{array}{l}\text { Cohesive: } \\
\text { Dentin (iv) }\end{array}$ & $\begin{array}{l}\text { Cohesive: } \\
\text { Post (v) }\end{array}$ & Mixed (vi) \\
\hline C & 3.33 & 58.33 & 5.00 & 1.67 & 1.67 & 30.00 \\
\hline $\mathrm{H}$ & 3.33 & 68.33 & 20.00 & - & 1.66 & 6.66 \\
\hline Cp10 & 15.25 & 54.23 & 13.55 & 1.69 & 3.38 & 11.86 \\
\hline Cp16 & 5.55 & 68.51 & 9.25 & 1.85 & 9.25 & 5.55 \\
\hline Cp37 & 1.66 & 70.00 & 15.00 & 3.33 & 5.00 & 5.00 \\
\hline SpW & 11.11 & 74.07 & 3.70 & - & 5.55 & 5.55 \\
\hline $\mathrm{SpH}$ & 6.66 & 83.33 & 1.66 & 1.66 & 6.66 & - \\
\hline
\end{tabular}

C - no bleaching agent; $\mathrm{H}-35 \%$ hydrogen peroxide; Cp10 - 10\% carbamide peroxide; $\mathrm{Cp} 16$ - 16\% carbamide peroxide; Cp37 - 37\% carbamide peroxide; $\mathrm{SpW}$ - sodium perborate + distilled water; $\mathrm{SpH}$ - sodium perborate $+20 \%$ hydrogen peroxide. 
$S$.
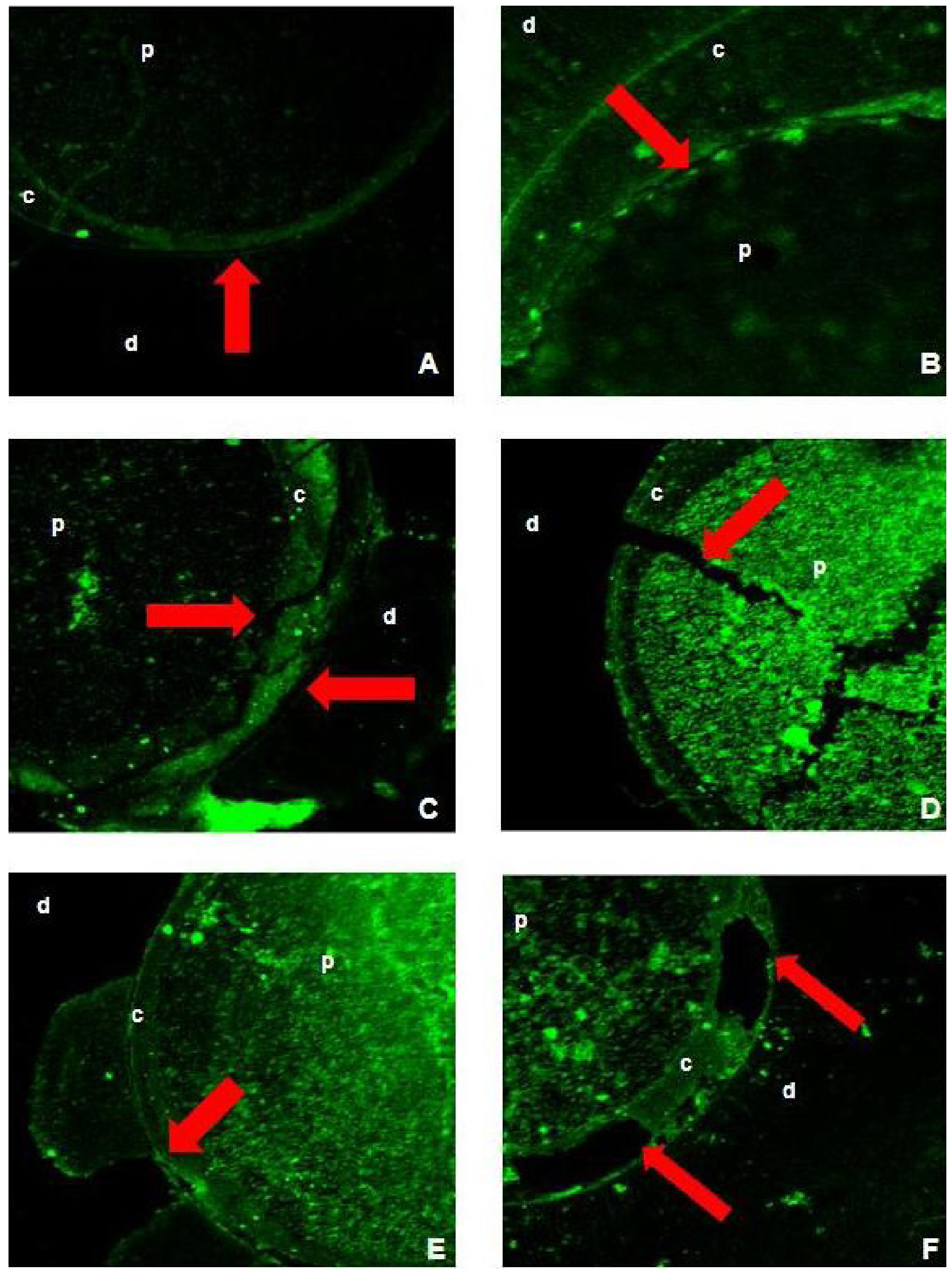

Figure 1. Confocal microscopy of failure mode: $\mathbf{A}$ - adhesive between resin cement and root dentine; $\mathbf{B}$ - adhesive between post and resin cement; C - mixed, among post, resin cement and root dentine; $\mathbf{D}$ - cohesive in post; $\mathbf{E}$ - cohesive in dentine; $\mathbf{F}$ - cohesive in cement. Red arrows point to failure region. $\mathbf{d}$ - dentin, $\mathbf{c}$ - cement and $\mathbf{p}$ - post. 


\section{DISCUSSION}

Internal bleaching agents did not reduce the bond strength of glass fiber posts to root dentine, but the bond to root dentine was affected by the different thirds of the root canal.

Previous studies validated the micro-push test, the experimental method used in this study, for measuring bond strength, which remains useful and necessary for the screening of new products and the study of experimental variables [26]. Push-out tests have a more homogenous stress distribution and less variability in mechanical testing [22].

Bovine teeth were used in this study because they are easier to collect and their age can be standardized [21,27]. According to previous studies, human and bovine teeth have similar properties [28-30].

The mechanism of tooth whitening may be summed up as an oxidation reduction reaction, where oxidizing substances applied in many different ways to dental hard tissues come into contact with substances that will be reduced, such as organic pigments in enamel and dentine. These pigments are cleaved into simple water-soluble molecular structures [3]. Basically, the oxidizing agent (hydrogen peroxide) releases free radicals and, after reduction, these pigments become water-soluble structures and free oxygen radicals. The penetration of hydrogen peroxide through dentin depends on the original concentration of the bleaching agent and the length of time during which the agent is in contact with the dentin [31,32]. The presence of residual oxygen on the surface or subsurface of the tooth structure may inhibit or limit the polymerization of composite resins and resin cements $[19,33,34]$, and bond strength may be reduced when bonding is performed immediately after bleaching $[35,36]$. In our study, bonding was performed 7 days after internal bleaching, according to the manufacturer's instructions. Moreover, the glass ionomer coronal sealing might have created an effective barrier against the penetration of the bleaching agent into the root canal.

The $\mathrm{SpH}$ group had lower bond strength values than the $\mathrm{Cp} 16$ group. Carbamide peroxide $(\mathrm{Cp})$ and sodium perborate $(\mathrm{Sp})$ are hydrogen peroxide $(\mathrm{Hp})$ precursors. $\mathrm{Cp}$ and $\mathrm{Sp}$ decompose, and the reaction releases $\mathrm{Hp}$, the active substance (oxidizing agent) in bleaching. Therefore, the association of $\mathrm{Sp}$ and $\mathrm{Hp}$ in the $\mathrm{SpH}$ group might explain the increase of the free oxygen radical concentration in comparison with the Cp16 group and, consequently, the decrease of bond strength values [37].

The analysis of the different root canal thirds in this study revealed that bond strength was greater in the cervical third and lower in the apical third in the Cp10, Cp16 and SpW groups. This difference may be associated with the cement used in this study (RelyX U100), which has high viscosity and, therefore, does not reach the apical third in some cases $[38,39]$. Furthermore, an adequate polymerization is necessary to achieve satisfactory mechanical properties. Achieving a reasonable degree of conversion with the use of light in the polymerization of resin cements is not easy, even when translucent glass fiber posts are used [40,41].

Confocal microscopy proved to be a satisfactory tool to analyze failure fracture, an important measure to predict the adhesive performance of different materials. Confocal microscopy consumes less time and does not require any preparation of the specimens [24]. In this study, adhesive cement-dentine failures were predominant in all groups (Table 2), a finding that may be associated with the bonding ability of the self-adhesive cement RelyX U100. This cement interacts chemically with the hydroxyapatite, and its ability to hybridize dentine is poor $[25,42,43]$.

Some of the limitations of this study were the fact that no method to age specimens, which might have simulated the oral environment better, and no antioxidant agents were used. Sodium ascorbate at $10 \%(\mathrm{SA})$ is a powerful hydro-soluble antioxidant capable of deoxidizing the reactions of oxygen and nitrogen free radical species. SA may prevent important deleterious oxidative effects on biological macromolecules, such as DNA, lipids, and proteins [44] and should, therefore, be included in future studies.

\section{CONCLUSION}

The use of internal bleaching agents does not decrease glass fiber post bond strength to root dentin. The cervical third had higher bond strength values than the apical third.

\section{REFERENCES}

1. Baratieri LN, Ritter AV, Monteiro S Jr, de Andrada MAC, Vieira LCC. Nonvital tooth bleaching: guidelines for the clinician. Quintess Int 1995;26(9) 597-608

2. Watts A, Addy M. Tooth discoloration and staining. A review of literature Braz Dent J 2001;190(6):309-16

3. Consolaro A, Franciscone LA, Consolaro RB, Carraro EAS. Escurecimento dentário por metamorfose cálcica da polpa e necrose pulpar asséptica. Rev Dent Press Est 2007;4(1):124-33.

4. Kinksbury CA. Discoloration of dentine. Dent Cosmos 1861;3(2):57-60.

5. Bogue EA. Bleaching Teeth. Dent Cosmos 1872;14(1):1-3

6. Harlan AW. The dental pulp, its destruction, and methods of treatment of teeth discolored by its retention in the pulp chamber or canals. Dent Cosmos 1891;33(1):137-41

7. Kirk EC. Hints, queries, and comments: sodium peroxide. Dent Cosmos 1893;35(1):1265-7.

8. Riehl H, Francci CE, Costa CAS, Ribeiro APD, Conceição EM. Clareamento de dentes vitais e não vitais: Uma visão crítica In: Fonseca AS Odontologia Estética: a arte da perfeição. Artes Médicas, São Paulo; 2008:1-68.

9. Titley KC, Torneck CD, Smith DC, Adibfar A. Adhesion of composite resin to bleached and unbleached bovine enamel. J Dent Res 1988;67(12) 1523-8. https://doi.org/10.1177/00220345880670121601

10. Torneck CD, Titley KC, Smith DC, Adibfar A. Adhesion of light cured composite resin to bleached and unbleached bovine dentine. Endod Dent Traumatol 1990;6(3):97-103. https://doi.org/10.1111/j.1600-9657.1990. tb00401.x

11. Shinohara MS, Peris AR, Pimenta LA, Ambrosano GM. Shear bond strength evaluation of composite resin on enamel and dentin after nonvital bleaching. J Esth Rest Dent 2005;17(1):22-9. https://doi. org/10.1111/j.1708-8240.2005.tb00078.x

12. Barcellos DC, Benetti P, Fernandes VV Jr, Valera MC. Effect of carbamide peroxide bleaching gel concentration on the bond strength of dental substrates and resin composite. Oper Dent 2010;35(4):463-9. https:// doi.org/10.2341/09-242-L

13. Dietrich AM, English J, McGrory K, Ontiveros J, Powers JM, Bussa HI Jr Salas-Lopez A. A comparison of shear bond strengths on bleached and unbleached bovine enamel. Texas Dent J 2010;127(3):285-91. 
14. Uysal T, Ertas H, Sagsen B, Bulut H, Er O, Ustdal A. Can intra-coronally bleached teeth be bonded safely after antioxidant treatment? Dent Mat 2010;29(1):47-52. https://doi.org/10.4012/dmi.2009-064

15. Cheung W. A review of the management of endodontically treated teeth Post, core and the final restoration. J Am Dent Assoc 2005;136(5): 611-9. https://doi.org/10.14219/jada.archive.2005.0232

16. Morgano SM. Restoration of pulpless teeth: application of traditional principles in present and future contexts. J Pros Dent 1996;75(4): 375-80. https://doi.org/10.1016/S0022-3913(96)90028-1

17. Morgano SM, Brackett SE. Foundation restorations in fixed prosthodontics: current knowledge and future needs. J Pros Dent 1999;82(6):643-57. https://doi.org/10.1016/S0022-3913(99)70005-3

18. Morgano SM, Rodrigues AH, Sabrosa CE. Restoration of endodontically treated teeth. Dent Clin North Am 2004;48(2):397-16. https://doi. org/10.1016/j.cden.2003.12.011

19. Ferrari M, Vichi A, Mannocci F, Mason PN. Retrospective study of the clinical performance of fiber posts. Am J Dent 2000;13(Special Issue): 9B-13B.

20. Campagnoli KR, Scholz Jr N. Clareamento de dentes desvitalizados: tecnica LED com peróxido de hidrogênio. Rev Clín Pesq Odont 2008;4(2):107-12

21. Soares CJ, Pereira JC, Valdivia ADCM, Novais VR, Meneses MS Influence of resin cement and post configuration on bond strength to root dentine. Int Endod J 2012;45(2):136-45. https://doi.org/10.1111/j.13652591.2011.01953.x

22. Soares CJ, Santana FR, Castro CG, Santos-Filho PCF, Soares PV, Qian F. Armstrong SR. Finite element analysis and Bond strength of a glass post to intraradicular dentin: comparison between microtensile and push-out tests. Dent Mat 2008;24(10):1405-11. https://doi.org/10.1016/j. dental.2008.03.004

23. Goracci C, Tavares AU, Fabianelli A, Monticelli F, Raffaelli O, Cardoso PC, Tay F, Ferrari M. The adhesion between fiber posts and root canal walls: comparison between microtensile and push-out bond strength measurements. Eur J Oral Sci 2004;112(4):353-61. https://doi. org/10.1111/j.1600-0722.2004.00146.x

24. Castellan CS, Santos-Filho PC, Soares PV, Soares CJ, Cardoso PE. Measuring bond strength between fiber post and root dentin: a comparison of different tests. J Adhes Dent 2010;12(6):477-85.

25. Bitter K, Paris S, Pfuertner C, Neumann K, Kielbassa AM. Morphological and bond strength evaluation of different resin cements to root dentin. Eur J Oral Sci 2009;117(3):326-33. https://doi.org/10.1111/j.16000722.2009.00623.x

26. Armstrong S, Geraldeli S, Maia R, Raposo LHA, Soares CJ, Yamagawa $\mathrm{J}$. Adhesion to tooth structure: A critical review of "micro" bond strength test method. Dent Mat 2010;26(2):50-62. https://doi.org/10.1016/j. dental.2009.11.155

27. Menezes MS, Queiroz EC, Campos RE, Martins LRM, Soares CJ. Influence of endodontic sealer cement on glass fiber post bond strength to root dentine. Int Endod J 2008;41(6):476-84. https://doi.org/10.1111/j.13652591.2008.01378.x

28. Nakamichi I, Iwaku M, Fusayama T. Bovine teeth as possible substitutes in the adhesion test. J Dent Res 1983;62(10):1076-81. https://doi.org/10 .1177/00220345830620101501

29. Dong CC, McComb D, Anderson JD, Tam LE. Effect of mode of polymerization of bonding agent on shear bond strength of autocured resin composite luting cements. J Can Dent Ass 2003;69(4): 229-34.
30. Soares CJ, Barbosa LM, Santana FR, Soares PBF, Mota AS, Silva GR, Fracture strength of composite fixed partial denture using bovine teeth as a substitute for human teeth with or without fiber-reinforcement. Braz Dent J 2010;21(3):235-40. https://doi.org/10.1590/S0103-64402010000300011

31. Hanks CT, Fat JC, Wataha JC, Concoran JF. Cytotoxicity and dentin permeability of carbamide peroxide and hydrogen peroxide vital bleaching materials in vitro. J Dent Res 1993;72(5):931-8. https://doi.org/10.1177/ 0022034593072005150

32. Benetti AR, Valera MC, Mancini MNG, Miranda CB, Balducci I. In vitro penetration of bleaching agents into the pulp chamber. Int Endod $J$ 2004;37(2):120-4. https://doi.org/10.1111/j.0143-2885.2004.00761.x

33. Miles PG, Pointer JP, Bahiraei D, Close J. The effect of carbamide peroxide bleaching on the tensile bond strength of ceramic brackets: An in vitro study. Am J Orth Dentofacial Orthoped 1994;106(4):371-5. https://doi. org/10.1016/S0889-5406(94)70058-3

34. Teixeira EC, Hara AT, Turssi CP, Serra MC. Effect of non-vital tooth bleaching on microleakage of coronal access restorations. J Oral Rehab 2003;30(11):1123-7. https://doi.org/10.1046/j.1365-2842.2003.01161.x

35. Titley KC, Torneck CD, Ruse ND. The effect of carbamide peroxide gel on the shear bond strength of a microfil resin to bovine enamel. J Dent Res 1992;71(1):20-4. https://doi.org/10.1177/00220345920710010301

36. Titley KC, Torneck CD, Ruse ND, Krmec D. Adhesion of a resin composite to bleached and unbleached human enamel. J Endod 1993;19(3): 112-5. https://doi.org/10.1016/S0099-2399(06)80504-2

37. Timpawat S, Nipattamanon C, Kijsamanmith K, Messer HH. Effect of bleaching agents on bonding to pulp chamber dentine. Int Endod J 2005;38(4):211-7. https://doi.org/10.1111/j.1365-2591.2004.00931.x

38. De Durão Mauricio PJ, González-López S, Aguilar-Mendoza JA, Félix S, González-Rodríguez MP. Comparison of regional bond strength in root thirds among fiber-reinforced posts luted with different cements. J Biom Mat Res Part B - Appl Biom 2007:83(2):364-72. https://doi.org/10.1002/ jbm.b.30805

39. Da Cunha LF, Furuse AY, Mondelli RF, Mondelli J. Compromised bond strength after root dentin deproteinization reversed with ascorbic acid. J Endod 2010;36(1):130-4. https://doi.org/10.1016/j.joen.2009.09.008

40. Yoldas O, Alaçam T. Microhardness of composites in simulated root canals cured with light transmitting posts and glassfiber reinforced composite posts. J Endod 2005:31(2):104-6. https://doi.org/10.1097/01. DON.0000133160.08600.47

41. Ceballos L, Garrido MA, Fuentes V, Rodríguez J. Mechanical characterization of resin cements used for luting fiber posts by nanoindentation. Dent Mat 2007;23(1):100-5. https://doi.org/10.1016/j. dental.2005.12.007

42. Gerth HU, Dammaschke T, Züchner H, Schäfer E. Chemical analysis and bonding reaction of RelyX Unicem and Bifix composites - a comparative study. Dent Mat 2006;22(10):934-41. https://doi.org/10.1016/j. dental.2005.10.004

43. Viotti RG, Kasaz A, Pena CE, Alexandre RS, Arrais CA, Reis AF Microtensile bond strength of new self-adhesive luting agents and conventional multistep systems. J Prost Dent 2009;102(5):306-12. https:/ doi.org/10.1016/S0022-3913(09)60180-3

44. Soheili Majd E, Goldberg M, Stanislawski L. In vitro effects of ascorbate and Trolox on the biocompatibility of dental restorative materials. Biomaterials 2003;24(1):3-9. https://doi.org/10.1016/S0142-9612(02)00221-1 